\title{
Lipid Abnormalities and Cardiometabolic Risk in Patients with Overt and Subclinical Thyroid Disease
}

\author{
Melpomeni Peppa, ${ }^{1}$ Grigoria Betsi, ${ }^{1}$ and George Dimitriadis ${ }^{2}$ \\ ${ }^{1}$ Endocrine Unit, Second Department of Internal Medicine-Propaedeutic, Research Institute and Diabetes Center, \\ Athens University Medical School, Attikon University Hospital, Athens, Greece \\ ${ }^{2}$ Second Department of Internal Medicine-Propaedeutic, Research Institute and Diabetes Center, Athens University Medical School, \\ Attikon University Hospital, Athens, Greece
}

Correspondence should be addressed to Melpomeni Peppa, molypepa@otenet.gr

Received 3 May 2011; Revised 17 May 2011; Accepted 17 May 2011

Academic Editor: Angeliki Chroni

Copyright ( $) 2011$ Melpomeni Peppa et al. This is an open access article distributed under the Creative Commons Attribution License, which permits unrestricted use, distribution, and reproduction in any medium, provided the original work is properly cited.

Dyslipidemia is a common finding in patients with thyroid disease, explained by the adverse effects of thyroid hormones in almost all steps of lipid metabolism. Not only overt but also subclinical hypo- and hyperthyroidism, through different mechanisms, are associated with lipid alterations, mainly concerning total and LDL cholesterol and less often HDL cholesterol, triglycerides, lipoprotein (a), apolipoprotein A1, and apolipoprotein B. In addition to quantitative, qualitative alterations of lipids have been also reported, including atherogenic and oxidized LDL and HDL particles. In thyroid disease, dyslipidemia coexists with various metabolic abnormalities and induce insulin resistance and oxidative stress via a vice-vicious cycle. The above associations in combination with the thyroid hormone induced hemodynamic alterations, might explain the increased risk of coronary artery disease, cerebral ischemia risk, and angina pectoris in older, and possibly ischemic stroke in younger patients with overt or subclinical hyperthyroidism.

\section{Introduction}

Thyroid disease, namely hypothyroidism and hyperthyroidism, constitutes the most common endocrine abnormality in recent years, diagnosed either in subclinical or clinical form. According to the 6-year duration NHANES III Study, the prevalence of hypothyroidism was $4.6 \%$ ( $0.3 \%$ clinical and $4.3 \%$ subclinical $)$ and of hyperthyroidism $1.3 \%(0.5 \%$ clinical and $0.7 \%$ subclinical), in population aged at least 12 years, showing an age and sex dependence [1].

Thyroid disease is associated with various metabolic abnormalities, due to the effects of thyroid hormones on nearly all major metabolic pathways. Thyroid hormones regulate the basal energy expenditure through their effect on protein, carbohydrate, and lipid metabolism. This might be a direct effect or an indirect effect by modification of other regulatory hormones such as insulin or catecholamines [2]. Dyslipidemia is a common metabolic abnormality in patients with thyroid disease, either in the overt or subclinical forms of the disease, and constitutes the end result of the effect of thyroid hormones in all aspects of lipid metabolism leading to various quantitative and/or qualitative changes of triglycerides, phospholipids, cholesterol, and other lipoproteins [3].

In thyroid disease, dyslipidemia and the coexisting metabolic abnormalities, in combination with the thyroid hormone-induced hemodynamic alterations, explain the high risk for cardiovascular disease [4-7].

\section{Effects of Thyroid Hormones on Lipid Metabolism}

Thyroid hormones influence all aspects of lipid metabolism including synthesis, mobilization, and degradation [3]. Thyroid hormones stimulate cholesterol synthesis by inducing 3-hydroxy-3-methyl-glutaryl coenzyme A reductase in the liver [8]. Thyroid hormones affect lipoprotein lipase activity and thus, the hydrolysis of triglycerides into very-low, density lipoprotein (VLDL) and chylomicrons into fatty 
TABLE 1: Changes in enzyme activities, transfer proteins, and receptors involved in lipid metabolism induced by thyroid hormones.

\begin{tabular}{ll}
\hline $\begin{array}{l}\text { Enzymes, transfer proteins, and liver } \\
\text { receptors }\end{array}$ & Thyroid hormone effect \\
\hline $\begin{array}{ll}\text { 3-hydroxy-3-methyl-glutaryl coenzyme } \\
\text { A reductase }\end{array}$ & $\uparrow$ \\
Adipose lipoprotein lipase & $\begin{array}{l}\text { Usually normal (may be } \\
\downarrow \text { in hypothyroidism) }\end{array}$ \\
Hepatic lipase & $\uparrow$ \\
Cholesteryl ester transfer protein & $\uparrow$ \\
ATP-binding cassette transporter A1 & $\downarrow$ \\
Acetyl-CoA carboxylase 1 & $\uparrow$ \\
Carnitine palmitoyltransferase Ia & $\uparrow$ \\
7alpha-hydroxylase & $\downarrow$ \\
LDL receptor & $\uparrow$ \\
\hline
\end{tabular}

acids and glycerol [3]. In hypothyroidism, lipoprotein lipase activity in the adipose tissue has been found normal or decreased, in addition to decreased hepatic lipase activity resulting in normal or high levels of triglycerides [9-11]. In hyperthyroidism, although lipoprotein lipase activity is usually normal $[10,12]$, an increased liver fatty acid synthesis and oxidation is observed due to enhanced acetyl-CoA carboxylase 1 and carnitine palmitoyltransferase Ia expression leading to increased VLDL biosynthesis $[13,14]$. Thyroid hormones affect cholesteryl ester transfer protein and hepatic lipase activity, which are increased in hyperthyroidism and decreased in hypothyroidism, with consequent changes not only in total high-density lipoprotein (HDL) but also in HDL subfraction levels $[12,15]$. Furthermore, thyroid hormones, by binding to the thyroid hormone receptor, inhibit through a competitive action the liver X-receptor-mediated ATPbinding cassette transporter $\mathrm{Al}$ gene expression, resulting in decreased HDL levels in patients with hyperthyroidism and increased in hypothyroidism $[14,16]$. Experimental evidence suggests that thyroid hormones might also affect cholesterol-7alpha-hydroxylase in liver [17, 18]. Thyroid hormones, especially triiodothyronine (T3), induce lowdensity lipoprotein (LDL) receptor gene expression in the liver, enhancing LDL clearance and explaining the decreased or increased LDL levels observed in hyperthyroidism and hypothyroidism, respectively [3]. Thyroid receptors seem to mediate the effects of thyroid hormones on lipid metabolism, and more specifically alpha 1 receptors control the lipogenesis in white adipose tissue, and $\beta$ receptors regulate the activity of lipogenic and lipolytic enzymes in the liver $[3,14]$. The changes induced by thyroid hormones in enzyme activities, transfer proteins, and liver receptors involved in lipid metabolism are summarized in Table 1.

Dyslipidemia is also due to the coexisting metabolic abnormalities in thyroid disease including oxidative stress and insulin resistance, which induce further or aggravate the existed dyslipidemia, via a vice-vicious cycle [19-28].

The lipid abnormalities observed in thyroid disorders are presented in Table 2.

\section{Lipid Abnormalities in Hypothyroidism}

Dyslipidemia is a common finding in patients with clinical hypothyroidism, consisting of high levels of total and LDL cholesterol [3, 28-30]. Data regarding triglycerides, lipoprotein (a) (Lp(a)), HDL, apolipoprotein B (apoB), and apolipoprotein $\mathrm{A} 1$ (apoA1) components are scarce, reporting either higher or similar to euthyroid subjects levels [3, 22, 2834] (Table 2). Qualitative changes of various lipid components have also been reported in clinical hypothyroidism, such as the enhanced LDL oxidation, reflected on the increased levels of markers of lipid peroxidation, such as MDA and thiobarbituric acid-reactive substances [19-24,35].

The observed abnormalities in total and LDL cholesterol are associated with the changes in the thyroid hormone levels in hypothyroidism, as they are significantly improved after thyroxine replacement treatment [29, 30, 36-40]. However, triglycerides, apoB, apoA1, Lp(a) levels, and qualitative abnormalities might be normalized or remained unchanged after treatment, suggesting a more complex cause of dyslipidemia in hypothyroidism $[29,31,36-43]$.

Subclinical hypothyroidism is also associated with lipid abnormalities, including mainly increased total and LDL cholesterol in most [3, 28-30, 44-53], but not all [54-57], studies. In contrast, HDL, triglycerides, $\mathrm{Lp}(\mathrm{a})$, apoB, and apoA1 levels did not exhibit any difference between patients with subclinical hypothyroidism and controls in the majority [29, 44-57], but not all [33, 44-48, 50, 55, 58-61], studies. Rondeau et al. found that TSH was negatively correlated with HDL-C in euthyroid overweight or obese postmenopausal women [62]. A quite recent study showed that transfer of triglycerides to HDL and phospholipids was lower in patients with subclinical hypothyroidism than that in controls while transfer of free and esterified cholesterol to HDL, HDL particle size, and paraoxonase 1 activity did not exhibit any difference [63] (Table 2).

Regarding the effects of treatment of subclinical hypothyroidism, the majority of studies suggest a normalization of total and LDL cholesterol levels after thyroxine substitution therapy [28, 30, 40-43, 48, 49, 52, 53, 64-67]. However, there are few trials where LDL did not significantly fall after treatment $[29,46,51]$, especially if the pretreatment TSH levels were less than $10 \mathrm{mIU} / \mathrm{L}[49,68]$. Triglycerides, HDL, apoA1, apoB, and $\operatorname{Lp}(\mathrm{a})$ levels are less influenced by thyroxine treatment in the majority of studies in subclinical hypothyroidism [ $28-30,38,43-49,52,53,58,65,66]$. However, few studies exist that showed improved HDL, apoA1, apoB, and/or $\operatorname{Lp}(\mathrm{a})$ levels after treatment of subclinical hypothyroidism [46-48, 51, 52, 58, 61, 67]. A quite recent study showed that the reduced transfer of triglycerides to HDL and phospholipids in subclinical hypothyroidism was fully reversed by achievement of euthyroidism [69].

\section{Lipid Abnormalities in Hyperthyroidism}

Most of the existing studies support lower total and LDL cholesterol levels in patients with hyperthyroidism $[3,32,39,68-$ 73], while only a few data support no change [21]. Lower triglycerides, HDL, apoA1, apoB, and $\mathrm{Lp}(\mathrm{a})$ levels have been 
TABLE 2: Lipid abnormalities in clinical and subclinical thyroid disorders.

\begin{tabular}{lllll}
\hline & Clinical hypothyroidism & $\begin{array}{l}\text { Subclinical } \\
\text { hypothyroidism }\end{array}$ & Clinical hyperthyroidism & $\begin{array}{l}\text { Subclinical } \\
\text { hyperthyroidism }\end{array}$ \\
\hline Total cholesterol & Increased & Increased or unaltered & $\begin{array}{l}\text { Decreased } \\
\text { (rarely unaltered) }\end{array}$ & Decreased or unaltered \\
LDL & Increased & $\begin{array}{l}\text { Increased } \\
\text { (rarely unaltered) }\end{array}$ & $\begin{array}{l}\text { Decreased } \\
\text { (rarely unaltered) }\end{array}$ & Decreased or unaltered \\
HDL & Unaltered or increased & $\begin{array}{l}\text { Unaltered } \\
\text { (rarely decreased) }\end{array}$ & Unaltered or decreased & $\begin{array}{l}\text { Unaltered? } \\
\text { (a few data exist) }\end{array}$ \\
Lipoprotein (a) & Unaltered or increased & $\begin{array}{l}\text { Unaltered } \\
\text { (rarely increased) }\end{array}$ & $\begin{array}{l}\text { Decreased? } \\
\text { (a few data exist) }\end{array}$ & $\begin{array}{l}\text { Unaltered? } \\
\text { (a few data exist) }\end{array}$ \\
Triglycerides & Unaltered or increased & $\begin{array}{l}\text { Unaltered } \\
\text { (rarely increased) }\end{array}$ & $\begin{array}{l}\text { Unaltered } \\
\text { (rarely decreased) }\end{array}$ & $\begin{array}{l}\text { Unaltered? } \\
\text { (a few data exist) }\end{array}$ \\
Apolipoprotein B & Unaltered or increased & Unaltered or increased & $\begin{array}{l}\text { Decreased? } \\
\text { (a few data exist) }\end{array}$ & $\begin{array}{l}\text { Unaltered? } \\
\text { (a few data exist) }\end{array}$ \\
Apolipoprotein A1 & Unaltered or increased & Unaltered (usually) & $\begin{array}{l}\text { Unaltered or decreased } \\
\text { Unaltered? } \\
\text { (a few data exist) }\end{array}$ \\
\hline
\end{tabular}

found in patients with hyperthyroidism compared with euthyroid controls, which is questionable by other reports [2123, 32, 68-72] (Table 2).

In hyperthyroidism, qualitative lipid changes, including increased levels of oxidized LDL, higher contents of thiobarbituric acid-reactive substances and dienes in LDL, low paraoxonase activity in HDL particles, and lower LDL content in antioxidant vitamin $\mathrm{E}$ and $\beta$-carotene have been found $[21,23,24,35]$.

The impact of treatment of hyperthyroidism on the lipid levels is not clear. Treatment with antithyroid drugs has been associated with elevated total and LDL cholesterol levels in some but not all studies [12, 21, 22, 68, 74-76]. Triglycerides are not affected by antithyroid treatment $[21,42,70,74,76]$. HDL, apoB, apoA1, Lp(a) levels have been found increased or unchanged after treatment [21, 22, 31, 42, 70-76].

The issue of lipid abnormalities in patients with subclinical hyperthyroidism has not been fully addressed. The existing data support normal levels of total LDL and HDL cholesterol, triglycerides, $\mathrm{Lp}(\mathrm{a})$, apoA1 and apoB while lower total and LDL cholesterol hav also e been reported $[77,78]$.

\section{Thyroid Disease and Cardiovascular Risk}

Most of the existing data supporting that thyroid disease is associated with increased cardiovascular risk which is mainly attributed to hemodynamic alterations as well as to a high risk of atherosclerosis [4-7].

5.1. Thyroid Disorders and Hemodynamic Changes. In hypothyroidism, the main functional cardiovascular disturbances involve decreased heart rate, elevated peripheral vascular resistance, increased diastolic blood pressure and cardiac afterload, reduced blood volume and cardiac preload, and diminished cardiac output. Impaired left ventricular systolic contractility at least during exercise and delayed left ventricular diastolic relaxation at rest and during exercise are common in both overt and subclinical hypothyroidism. Hy- pothyroidism is also associated with diastolic heart failure in the elderly $[4,7]$.

In hyperthyroidism, hemodynamic changes result mainly from increased $\beta 1$-adrenergic activity. Increased triiodothyronine levels exert positive inotropic and chronotropic effects, leading to enhanced heart rate and systolic contractility and, consequently, increased cardiac output. Increased triiodothyronine stimulates sarcoplasmic reticulum $\mathrm{Ca}$ ATPase, leading to systolic and diastolic dysfunction. Moreover, triiodothyronine reduces peripheral vascular resistance, causing a decrease in diastolic blood pressure and cardiac afterload, which further raises cardiac output. Decreased vascular resistance accounts for activation of renin-angiotensinaldosterone system, which increases blood volume and cardiac preload, augmenting cardiac output even more [5, 7]. Biondi et al. found that even patients with subclinical hyperthyroidism had significantly higher average heart rate, enhanced systolic function, impaired diastolic function with prolonged isovolumic relaxation time, and increased left ventricular mass compared with euthyroid subjects [79].

5.2. Thyroid Disease and Atherosclerosis. As mentioned above, thyroid disease is related to the development of dyslipidemia which is a well-known atherogenic factor. Dyslipidemia induces insulin resistance oxidative stress, via a vicevicious cycle [19-24, 35]. Insulin resistance, hypertension, inflammation, oxidative stress, and coagulation deficits are also promoted by thyroid disease, independently of dyslipidemia [4-7]. The above associations support a multifactorial origin of atherosclerosis in thyroid disease, with dyslipidemia playing an important role [4-7].

Overt hypothyroidism has been associated with diastolic hypertension $[4,6,7,80,81]$ and hyperhomocysteinemia [82-85]. Increased levels of high-sensitivity C-reactive protein and coagulation deficits have been reported in patients with hypothyroidism [83, 86-88]. Higher levels of homeostasis model assessment and lower levels of Matsuda indexes, suggesting insulin resistance, have been found in 
patients with overt hypothyroidism compared with euthyroid subjects in some $[25,26,89,90]$ but not all $[91,92]$ studies. Impaired intracellular glucose catabolism and GLUT4 translocation, decreased glycogen synthesis and glucose oxidation, and altered blood flow, have been proposed as underlying mechanisms $[25,26,90,93,94]$. Increased intima-media thickness of the common carotid artery has been reported in some studies in patients with overt hypothyroidism [53, 95, 96]. A higher frequency and/or severity of coronary heart disease $[4,97,98]$ and an increased ischemic stroke risk [99] have been reported in patients with overt hypothyroidism.

Subclinical hypothyroidism has been also associated with diastolic hypertension in most but not all studies [48, 60, $89,100-103]$. A few but not all studies have reported hyperhomocysteinemia $[48,83,104-108]$, higher but also normal levels of high-sensitivity C-reactive protein $[56,57$, 83,104,107, 109-111], and possible coagulation deficits $[86,87]$ in patients with subclinical hypothyroidism. Higher levels of homeostasis model assessment and lower levels of Matsuda indexes, suggesting insulin resistance, have been found in patients with subclinical hypothyroidism in some but not all studies $[25,26,89,104,111]$. Increased intimamedia thickness of the common carotid artery has been found in some studies in subclinical hypothyroidism [45, 53]. In the Whickham Survey, an association was found between incident coronary heart disease and related mortality in patients with subclinical hypothyroidism over the 20 yrs of followup, which was attenuated after levothyroxine treatment [112]. In support of this, 3 meta-analyses suggested that subclinical hypothyroidism is associated with a significant risk of coronary heart disease and cardiovascular mortality [113-115]. Another meta-analysis by Razvi et al. showed that the incidence and prevalence of coronary heart disease and the risk of cardiovascular mortality were higher in subclinical hypothyroidism, in patients younger than 65 years old and more prevalent in women [116]. Subclinical hypothyroidism has been associated with cerebral ischemia [117]. Although Jeong et al. in a study of 382 patients with ischemic stroke found no difference in the prevalence of subclinical hypothyroidism $(4,5 \%)$ compared to the general population, low-normal free T4 levels in euthyroid patients were independently associated with a higher percentage of ischemic stroke [118]. In addition, it has been demonstrated that patients with subclinical hypothyroidism (especially those with $\mathrm{TSH} \geq 10 \mu \mathrm{U} / \mathrm{mL}$ ) and acute ischemic stroke exhibited a better level of consciousness, a milder neurological deficit at presentation, and more favorable outcomes on the 30th and 90th day compared with euthyroid patients $[119,120]$. However, Rodondi et al. found no association between subclinical hypothyroidism and risk for stroke [121].

On the other hand, clinical hyperthyroidism has been associated with systolic hypertension, increased pulse pressure, and possibly hyperhomocysteinemia $[6,7,122,123]$ Additionally, patients with overt hyperthyroidism have a hypercoagulable state and an increased risk of thrombosis [86]. Higher levels of homeostasis model assessment and lower levels of Matsuda indexes have been reported, suggesting insulin resistance. [25, 27, 71, 91-93] Decreased fractional postprandial glucose uptake in adipose tissue, increased fasting lipolysis, increased interleukin 6 , and tumour necrosis factor alpha may be associated to its development $[25,93$, $124,125]$. Angina pectoris is a frequent disorder, especially in older patients with hyperthyroidism and underlying cardiac disease, and is due to increased heart rate and contractility and high myocardial oxygen demand [5]. Some cases of patients with hyperthyroidism due to Graves' disease presenting with coronary artery spasm have been reported [126-128]. Hyperthyroidism has been associated with a higher risk for ischemic stroke among young adults during a 5-year followup which was probably associated with atrial fibrillation $(\mathrm{AF})$, hypercoagulability and rarely antiphospholipid antibody syndrome [129-132].

Subclinical hyperthyroidism has been also associated with hypertension in some but not all studies [102, 103, 133]. Higher HOMA, lower Matsuda indexes [27], and increased carotid intima thickness [134] have been found in patients with subclinical hyperthyroidism. However, the association of subclinical hyperthyroidism with coronary heart disease risk and cardiovascular mortality is still unclear. Ochs et al. found a possible association, while the meta-analysis by Singh et al. found no significant association $[113,115]$. Jeong et al. in a study of 382 patients with ischemic stroke found no difference in the prevalence of subclinical hyperthyroidism $(1,6 \%)$ compared to the general population [118].

\section{Conclusion}

Thyroid hormones regulate the expression of enzymes involved in all steps of lipid metabolism leading to the development of qualitative and quantitative changes of lipids, in thyroid disease. Dyslipidemia coexists with other metabolic abnormalities, including, hypertension, insulin resistance, and oxidative stress, all of them being risk factors for cardiovascular disease. In addition, dyslipidemia induces insulin resistance and oxidative stress, via a vice-vicious cycle. The existing data support that there is an increased cardiovascular morbidity in patients with thyroid disease and possibly mortality which is in part mediated by the dyslipidemia or the dyslipidemia-induced metabolic abnormalities. However, more studies need to be done, especially prospective, to elucidate the real significance of dyslipidemia or other metabolic changes to CVD morbidity and mortality in clinical and, even more, in subclinical thyroid disease.

\section{References}

[1] J. G. Hollowell, N. W. Staehling, W. D. Flanders et al., "Serum TSH, T4, and thyroid antibodies in the United States population (1988 to 1994): National Health and Nutrition Examination Survey (NHANES III)," Journal of Clinical Endocrinology and Metabolism, vol. 87, no. 2, pp. 489-499, 2002.

[2] B. Kim, "Thyroid hormone as a determinant of energy expenditure and the basal metabolic rate," Thyroid, vol. 18, no. 2, pp. 141-144, 2008. 
[3] X. Zhu and S. Y. Cheng, "New insights into regulation of lipid metabolism by thyroid hormone," Current Opinion in Endocrinology, Diabetes and Obesity, vol. 17, no. 5, pp. 408413, 2010.

[4] B. Biondi and I. Klein, "Hypothyroidism as a risk factor for cardiovascular disease," Endocrine, vol. 24, no. 1, pp. 1-13, 2004.

[5] B. Biondi and G. J. Kahaly, "Cardiovascular involvement in patients with different causes of hyperthyroidism," Nature Reviews Endocrinology, vol. 6, no. 8, pp. 431-443, 2010.

[6] I. Klein and K. Ojamaa, "Thyroid hormone and the cardiovascular system," The New England Journal of Medicine, vol. 344, no. 7, pp. 501-509, 2001.

[7] S. Fazio, E. A. Palmieri, G. Lombardi, and B. Biondi, "Effects of thyroid hormone on the cardiovascular system," Recent Progress in Hormone Research, vol. 59, pp. 31-50, 2004.

[8] A. N. A. Cachefo, P. Boucher, C. Vidon, E. Dusserre, F. Diraison, and M. Beylot, "Hepatic lipogenesis and cholesterol synthesis in hyperthyroid patients," Journal of Clinical Endocrinology and Metabolism, vol. 86, no. 11, pp. 53535357, 2001.

[9] J. J. Abrams, S. M. Grundy, and H. Ginsberg, "Metabolism of plasma triglycerides in hypothyroidism and hyperthyroidism in man," Journal of Lipid Research, vol. 22, no. 2, pp. 307-322, 1981.

[10] K. S. L. Lam, M. K. Chan, and R. T. T. Yeung, "Highdensity lipoprotein cholesterol, hepatic lipase and lipoprotein lipase activities in thyroid dysfunction-effects of treatment," Quarterly Journal of Medicine, vol. 59, no. 229, pp. 513-521, 1986.

[11] R. M. Krauss, R. I. Levy, and D. S. Fredrickson, "Selective measurement of two lipase activities in postheparin plasma from normal subjects and patients with hyperlipoproteinemia," Journal of Clinical Investigation, vol. 54, no. 5, pp. 11071124, 1974.

[12] K. C. B. Tan, S. W. M. Shiu, and A. W. C. Kung, "Effect of thyroid dysfunction on high-density lipoprotein subfraction metabolism: roles of hepatic lipase and cholesteryl ester transfer protein," Journal of Clinical Endocrinology and Metabolism, vol. 83, no. 8, pp. 2921-2924, 1998.

[13] M. Heimberg, J. O. Olubadewo, and H. G. Wilcox, "Plasma lipoproteins and regulation of hepatic metabolism of fatty acids in altered thyroid states," Endocrine Reviews, vol. 6, no. 4, pp. 590-607, 1985.

[14] Y. Y. Liu and G. A. Brent, "Thyroid hormone crosstalk with nuclear receptor signaling in metabolic regulation," Trends in Endocrinology and Metabolism, vol. 21, no. 3, pp. 166-173, 2010.

[15] J. A. Berti, M. E. C. Amaral, A. C. Boschero et al., “Thyroid hormone increases plasma cholesteryl ester transfer protein activity and plasma high-density lipoprotein removal rate in transgenic mice," Metabolism, vol. 50, no. 5, pp. 530-536, 2001.

[16] I. Tancevski, A. Wehinger, E. Demetz et al., "Reduced plasma high-density lipoprotein cholesterol in hyperthyroid mice coincides with decreased hepatic adenosine 5 '-triphosphatebinding cassette transporter 1 expression," Endocrinology, vol. 149, no. 7, pp. 3708-3712, 2008.

[17] G. Sauter, M. Weiss, and R. Hoermann, "Cholesterol $7 \alpha$ hydroxylase activity in hypothyroidism and hyperthyroidism in humans," Hormone and Metabolic Research, vol. 29, no. 4, pp. 176-179, 1997.
[18] V. A. B. Drover and L. B. Agellon, "Regulation of the human cholesterol $7 \alpha$-hydroxylase gene (CYP7A1) by thyroid hormone in transgenic mice," Endocrinology, vol. 145, no. 2, pp. 574-581, 2004.

[19] A. Santi, M. M. M. F. Duarte, R. N. Moresco et al., "Association between thyroid hormones, lipids and oxidative stress biomarkers in overt hypothyroidism," Clinical Chemistry and Laboratory Medicine, vol. 48, no. 11, pp. 1635-1639, 2010.

[20] N. Nanda, Z. Bobby, and A. Hamide, "Association of thyroid stimulating hormone and coronary lipid risk factors with lipid peroxidation in hypothyroidism," Clinical Chemistry and Laboratory Medicine, vol. 46, no. 5, pp. 674-679, 2008.

[21] D. G. Yavuz, M. Yüksel, O. Deyneli, Y. Ozen, H. Aydin, and S. Akalin, "Association of serum paraoxonase activity with insulin sensitivity and oxidative stress in hyperthyroid and TSH-suppressed nodular goitre patients," Clinical Endocrinology, vol. 61, no. 4, pp. 515-521, 2004.

[22] V. Sundaram, A. N. Hanna, L. Koneru, H. A. I. Newman, and J. M. Falko, "Both hypothyroidism and hyperthyroidism enhance low density lipoprotein oxidation," Journal of Clinical Endocrinology and Metabolism, vol. 82, no. 10, pp. 34213424, 1997.

[23] F. Costantini, S. D. Pierdomenico, D. De Cesare et al., "Effect of thyroid function on LDL oxidation," Arteriosclerosis, Thrombosis, and Vascular Biology, vol. 18, no. 5, pp. 732-737, 1998.

[24] T. Diekman, P. N. M. Demacker, J. J. P. Kastelein, A. F. H. Stalenhoef, and W. M. Wiersinga, "Increased oxidizability of low-density lipoproteins in hypothyroidism," Journal of Clinical Endocrinology and Metabolism, vol. 83, no. 5, pp. 1752-1755, 1998.

[25] M. Peppa, C. Koliaki, P. Nikolopoulos, and S. A. Raptis, "Skeletal muscle insulin resistance in endocrine disease," Journal of Biomedicine and Biotechnology, vol. 2010, Article ID 527850, 2010.

[26] E. Maratou, D. J. Hadjidakis, A. Kollias et al., "Studies of insulin resistance in patients with clinical and subclinical hypothyroidism," European Journal of Endocrinology, vol. 160, no. 5, pp. 785-790, 2009.

[27] E. Maratou, D. J. Hadjidakis, M. Peppa et al., "Studies of insulin resistance in patients with clinical and subclinical hyperthyroidism," European Journal of Endocrinology, vol. 163, no. 4, pp. 625-630, 2010.

[28] T. Tagami, T. Tamanaha, S. Shimazu et al., "Lipid profiles in the untreated patients with Hashimoto thyroiditis and the effects of thyroxine treatment on subclinical hypothyroidism with Hashimoto thyroiditis," Endocrine Journal, vol. 57, no. 3, pp. 253-258, 2010.

[29] T. Tzotzas, G. E. Krassas, T. Konstantinidis, and M. Bougoulia, "Changes in lipoprotein(a) levels in overt and subclinical hypothyroidism before and during treatment," Thyroid, vol. 10, no. 9, pp. 803-808, 2000.

[30] P. D. F. D. S. Teixeira, V. S. Reuters, M. M. Ferreira et al., "Lipid profile in different degrees of hypothyroidism and effects of levothyroxine replacement in mild thyroid failure," Translational Research, vol. 151, no. 4, pp. 224-231, 2008.

[31] T. W. A. de Bruin, H. Van Barlingen, M. Van Linde-Sibenius Trip, A. R. R. Van Vuurst de Vries, M. J. Akveld, and D. W. Erkelens, "Lipoprotein(a) and apolipoprotein B plasma concentrations in hypothyroid, euthyroid, and hyperthyroid subjects," Journal of Clinical Endocrinology and Metabolism, vol. 76, no. 1, pp. 121-126, 1993. 
[32] A. Raziel, B. Rosenzweig, V. Botvinic et al., "The influence of thyroid function on serum lipid profile," Atherosclerosis, vol. 41, no. 2-3, pp. 321-326, 1982.

[33] J. J. Staub, B. U. Althaus, H. Engler et al., "Spectrum of subclinical and overt hypothyroidism: effect on thyrotropin, prolactin, and thyroid reserve, and metabolic impact on peripheral target tissues," American Journal of Medicine, vol. 92, no. 6, pp. 631-642, 1992.

[34] R. P. F. Dullaart, J. J. van Doormaal, K. Hoogenberg, and W. J. Sluiter, "Triiodothyronine rapidly lowers plasma lipoprotein (a) in hypothyroid subjects," Netherlands Journal of Medicine, vol. 46, no. 4, pp. 179-184, 1995.

[35] A. N. Torun, S. Kulaksizoglu, M. Kulaksizoglu, B. O. Pamuk, E. Isbilen, and N. B. Tutuncu, "Serum total antioxidant status and lipid peroxidation marker malondialdehyde levels in overt and subclinical hypothyroidism," Clinical Endocrinology, vol. 70, no. 3, pp. 469-474, 2009.

[36] A. Becerra, D. Bellido, A. Luengo, G. Piédrola, and D. A. De Luis, "Lippprotein(a) and other lipoproteins in hypothyroid patients before and after thyroid replacement therapy," Clinical Nutrition, vol. 18, no. 5, pp. 319-322, 1999.

[37] I. C. Klausen, F. E. Nielsen, L. Hegedus, L. U. Gerdes, P. Charles, and O. Faergeman, "Treatment of hypothyroidism reduces low-density lipoproteins but not lipoprotein(a)," Metabolism, vol. 41, no. 8, pp. 911-914, 1992.

[38] M. Ito, T. Arishima, T. Kudo et al., "Effect of levo-thyroxine replacement on non-high-density lipoprotein cholesterol in hypothyroid patients," Journal of Clinical Endocrinology and Metabolism, vol. 92, no. 2, pp. 608-611, 2007.

[39] M. Paoli, G. Bellabarba, E. Velazquez et al., "Sex steroids, lipids, and lipoprotein cholesterols in women with subclinical and overt hypothyroidism before and after L-thyroxine therapy," Clinica Chimica Acta, vol. 275, no. 1, pp. 81-91, 1998.

[40] F. Pazos, J. J. Alvarez, J. Rubies-Prat, C. Varela, and M. A. Lasuncion, "Long term thyroid replacement therapy and levels of lipoprotein(a) and other lipoproteins," Journal of Clinical Endocrinology and Metabolism, vol. 80, no. 2, pp. 562-566, 1995.

[41] M. L. Martánez-Triguero, A. Hernández-Mijares, T. T. Nguyen et al., "Effect of thyroid hormone replacement on lipoprotein(a), lipids, and apolipoproteins in subjects with hypothyroidism," Mayo Clinic Proceedings, vol. 73, no. 9, pp. 837-841, 1998.

[42] T. O’Brien, K. Katz, D. Hodge, T. T. Nguyen, B. A. Kottke, and I. D. Hay, "The effect of the treatment of hypothyroidism and hyperthyroidism on plasma lipids and apolipoproteins AI, AII and E," Clinical Endocrinology, vol. 46, no. 1, pp. 1720, 1997.

[43] R. Arem, D. A. Escalante, N. Arem, J. D. Morrisett, and W. Patsch, "Effect of L-thyroxine therapy on lipoprotein fractions in overt and subclinical hypothyroidism, with special reference to lipoprotein(a)," Metabolism, vol. 44, no. 12, pp. 1559-1563, 1995.

[44] N. Caraccio, E. Ferrannini, and F. Monzani, "Lipoprotein profile in subclinical hypothyroidism: response to levothyroxine replacement, a randomized placebo-controlled study," Journal of Clinical Endocrinology and Metabolism, vol. 87, no. 4, pp. 1533-1538, 2002.

[45] F. Monzani, N. Caraccio, M. Kozàkowà et al., "Effect of levothyroxine replacement on lipid profile and intima-media thickness in subclinical hypothyroidism: a double-blind, placebo- controlled study," Journal of Clinical Endocrinology and Metabolism, vol. 89, no. 5, pp. 2099-2106, 2004.

[46] Z. Efstathiadou, S. Bitsis, H. J. Milionis et al., "Lipid profile in subclinical hypothyroidism: is L-thyroxine substitution beneficial?" European Journal of Endocrinology, vol. 145, no. 6, pp. 705-710, 2001.

[47] A. Iqbal, R. Jorde, and Y. Figenschau, "Serum lipid levels in relation to serum thyroid-stimulating hormone and the effect of thyroxine treatment on serum lipid levels in subjects with subclinical hypothyroidism: the Tromsø Study," Journal of Internal Medicine, vol. 260, no. 1, pp. 53-61, 2006.

[48] M. Adrees, J. Gibney, N. El-Saeity, and G. Boran, "Effects of 18 months of 1-T4 replacement in women with subclinical hypothyroidism," Clinical Endocrinology, vol. 71, no. 2, pp. 298-303, 2009.

[49] S. Miura, M. Iitaka, H. Yoshimura et al., "Disturbed lipid metabolism in patients with subclinical hypothyroidism: effect of L-thyroxine therapy," Internal Medicine, vol. 33, no. 7, pp. 413-417, 1994.

[50] A. W. C. Kung, R. W. C. Pang, and E. D. Janus, "Elevated serum lipoprotein(a) in subclinical hypothyroidism," Clinical Endocrinology, vol. 43, no. 4, pp. 445-449, 1995.

[51] M. Ito, J. Takamatsu, I. Sasaki et al., "Disturbed metabolism of remnant lipoproteins in patients with subclinical hypothyroidism," American Journal of Medicine, vol. 117, no. 9, pp. 696-699, 2004.

[52] E. S. Ganotakis, K. Mandalaki, M. Tampakaki et al., "Subclinical hypothyroidism and lipid abnormalities in older women attending a vascular disease prevention clinic: effect of thyroid replacement therapy," Angiology, vol. 54, no. 5, pp. 569-576, 2003.

[53] S. K. Kim, S. H. Kim, K. S. Park, S. W. Park, and Y. W. Cho, "Regression of the increased common carotid artery-intima media thickness in subclinical hypothyroidism after thyroid hormone replacement," Endocrine Journal, vol. 56, no. 6, pp. 753-758, 2009.

[54] W. J. Hueston and W. S. Pearson, "Subclinical hypothyroidism and the risk of hypercholesterolemia," Annals of Family Medicine, vol. 2, no. 4, pp. 351-355, 2004.

[55] S. K. A. Shakoor, A. Aldibbiat, L. E. Ingoe et al., "Endothelial progenitor cells in subclinical hypothyroidism: the effect of thyroid hormone replacement therapy," Journal of Clinical Endocrinology and Metabolism, vol. 95, no. 1, pp. 319-322, 2010.

[56] R. J. Bell, L. Rivera-Woll, S. L. Davison, D. J. Topliss, S. Donath, and S. R. Davis, "Well-being, health-related quality of life and cardiovascular disease risk profile in women with subclinical thyroid disease-a community-based study," Clinical Endocrinology, vol. 66, no. 4, pp. 548-556, 2007.

[57] J. Kvetny, P. E. Heldgaard, E. M. Bladbjerg, and J. Gram, "Subclinical hypothyroidism is associated with a low-grade inflammation, increased triglyceride levels and predicts cardiovascular disease in males below 50 years," Clinical Endocrinology, vol. 61, no. 2, pp. 232-238, 2004.

[58] M. Yildirimkaya, M. Özata, K. Yilmaz, C. Kilinç, M. A. Gündoğan, and T. Kutluay, "Lipoprotein(a) Concentration in Subclinical Hypothyroidism before and after Levo-Thyroxine Therapy," Endocrine Journal, vol. 43, no. 6, pp. 731-736, 1996.

[59] P. Caron, C. Calazel, H. J. Parra, M. Hoff, and J. P. Louvet, "Decreased HDL cholesterol in subclinical hypothyroidism: the effect of L-thyroxine therapy," Clinical Endocrinology, vol. 33, no. 4, pp. 519-523, 1990. 
[60] Y. Lai, J. Wang, F. Jiang et al., "The relationship between serum thyrotropin and components of metabolic syndrome," Endocrine Journal, vol. 58, no. 1, pp. 23-30, 2011.

[61] H. J. Milionis, Z. Efstathiadou, A. D. Tselepis et al., "Lipoprotein (a) levels and apolipoprotein (a) isoform size in patients with subclinical hypothyroidism: effect of treatment with levothyroxine," Thyroid, vol. 13, no. 4, pp. 365-369, 2003.

[62] G. Rondeau, N. Rutamucero, V. Messier et al., "Reference range thyroid-stimulating hormone is associated with physical activity energy expenditure in overweight and obese postmenopausal women: a Montreal-Ottawa New Emerging Team Study," Metabolism, vol. 59, no. 11, pp. 1597-1602, 2010.

[63] G. A. Sigal, G. Medeiros-Neto, J. C. Vinagre, J. Diament, and R. C. Maranhão, "Lipid metabolism in subclinical hypothyroidism: plasma kinetics of triglyceride-rich lipoproteins and lipid transfers to high-density lipoprotein before and after levothyroxine treatment," Thyroid, vol. 21, no. 4, pp. 347353, 2011.

[64] J. A. Franklyn, J. Daykin, J. Betteridge et al., "Thyroxine replacement therapy and circulating lipid concentrations," Clinical Endocrinology, vol. 38, no. 5, pp. 453-459, 1993.

[65] M. Weintraub, I. Grosskopf, Y. Trostanesky, G. Charach, A. Rubinstein, and N. Stern, "Thyroxine replacement therapy enhances clearance of chylomicron remnants in patients with hypothyroidism," Journal of Clinical Endocrinology and Metabolism, vol. 84, no. 7, pp. 2532-2536, 1999.

[66] C. Meier, J. J. Staub, C. B. Roth et al., "TSH-controlled L-thyroxine therapy reduces cholesterol levels and clinical symptoms in subclinical hypothyroidism: a double blind, placebo-controlled trial (basel thyroid study)," Journal of Clinical Endocrinology and Metabolism, vol. 86, no. 10, pp. 4860-4866, 2001.

[67] R. Arem and W. Patsch, "Lipoprotein and apolipoprotein levels in subclinical hypothyroidism. Effect of levothyroxine therapy," Archives of Internal Medicine, vol. 150, no. 10, pp. 2097-2100, 1990.

[68] H. Nishitani, K. Okamura, S. Noguchi, K. Inoue, Y. Morotomi, and M. Fujishima, "Serum lipid levels in thyroid dysfunction with special reference to transient elevation during treatment in hyperthyroid graves' disease," Hormone and Metabolic Research, vol. 22, no. 9, pp. 490-493, 1990.

[69] X. Guang-Da, C. Hong-Yan, and Z. Xian-Mei, "Changes in endothelium-dependent arterial dilation before and after subtotal thyroidectomy in subjects with hyperthyroidism," Clinical Endocrinology, vol. 61, no. 3, pp. 400-404, 2004.

[70] E. Muls, V. Blaton, and M. Rosseneu, "Serum lipids and apolipoproteins A-I, A-II, and B in hyperthyroidism before and after treatment," Journal of Clinical Endocrinology and Metabolism, vol. 55, no. 3, pp. 459-464, 1982.

[71] A. E. Altinova, F. B. Törüner, M. Aktürk et al., "Adiponectin levels and cardiovascular risk factors in hypothyroidism and hyperthyroidism," Clinical Endocrinology, vol. 65, no. 4, pp. 530-535, 2006.

[72] A. W. C. Kung, R. W. C. Pang, I. Lauder, K. S. L. Lam, and E. D. Janus, "Changes in serum lipoprotein(a) and lipids during treatment of hyperthyroidism," Clinical Chemistry, vol. 41, no. 2, pp. 226-231, 1995.

[73] I. C. Klausen, L. Hegedus, P. S. Hansen, F. E. Nielsen, L. U. Gerdes, and O. Faergeman, "Apolipoprotein(a) phonotypes and lipoprotein (a) concentrations in patients with hyperthyroidism," Journal of Molecular Medicine, vol. 73, no. 1, pp. 41-46, 1995.
[74] M. Ozata, M. Yildirimkaya, K. Yilmaz et al., "The effects of thyroid status on serum apolipoprotein A-I-containing lipoprotein particles," Hormone and Metabolic Research, vol. 30, no. 4, pp. 217-221, 1998.

[75] H. Hayashi, N. Mizushima, H. Yoshinaga et al., "The relationship between lipoprotein(a) and low density lipoprotein receptors during the treatment of hyperthyroidism," Hormone and Metabolic Research, vol. 28, no. 8, pp. 384-387, 1996.

[76] F. Hoppichler, C. Sandholzer, R. Moncayo, G. Utermann, and H. G. Georg Kraft, "Thyroid hormone (fT4) reduces lipoprotein(a) plasma levels," Atherosclerosis, vol. 115, no. 1, pp. 65-71, 1995.

[77] A. Berghout, J. van de Wetering, and P. Klootwijk, "Cardiac and metabolic effects in patients who present with a multinodular goitre," Netherlands Journal of Medicine, vol. 61, no. 10, pp. 318-322, 2003.

[78] J. V. Parle, J. A. Franklyn, K. W. Cross, S. R. Jones, and M. C. Sheppard, "Circulating lipids and minor abnormalities of thyroid function," Clinical Endocrinology, vol. 37, no. 5, pp. 411-414, 1992.

[79] B. Biondi, E. A. Palmieri, S. Fazio et al., "Endogenous subclinical hyperthyroidism affects quality of life and cardiac morphology and function in young and middle-aged patients," Journal of Clinical Endocrinology and Metabolism, vol. 85, no. 12, pp. 4701-4705, 2000.

[80] V. Kotsis, M. Alevizaki, S. Stabouli et al., "Hypertension and hypothyroidism: results from an ambulatory blood pressure monitoring study," Journal of Hypertension, vol. 25, no. 5, pp. 993-999, 2007.

[81] I. Saito, K. Ito, and T. Saruta, "Hypothyroidism as a cause of hypertension," Hypertension, vol. 5, no. 1, pp. 112-115, 1983.

[82] O. Mayer, J. Šimon, J. Filipovský, M. Pláškova, and R. Pikner, "Hypothyroidism in coronary heart disease and its relation to selected risk factors," Vascular Health and Risk Management, vol. 2, no. 4, pp. 499-506, 2006.

[83] M. Christ-Crain, C. Meier, M. Guglielmetti et al., "Elevated C-reactive protein and homocysteine values: cardiovascular risk factors in hypothyroidism? A cross-sectional and a double-blind, placebo-controlled trial," Atherosclerosis, vol. 166, no. 2, pp. 379-386, 2003.

[84] B. G. Nedrebø, U. B. Ericsson, O. Nygård et al., "Plasma total homocysteine levels in hyperthyroid and hypothyroid patients," Metabolism, vol. 47, no. 1, pp. 89-93, 1998.

[85] M. S. Morris, A. G. Bostom, P. F. Jacques, J. Selhub, and I. H. Rosenberg, "Hyperhomocysteinemia and hypercholesterolemia associated with hypothyroidism in the third US National Health and Nutrition Examination Survey," Atherosclerosis, vol. 155, no. 1, pp. 195-200, 2001.

[86] A. Squizzato, E. Romualdi, H. R. Büller, and V. E. A. Gerdes, "Clinical review: thyroid dysfunction and effects on coagulation and fibrinolysis: a systematic review," Journal of Clinical Endocrinology and Metabolism, vol. 92, no. 7, pp. 2415-2420, 2007.

[87] C. Erem, "Coagulation and fibrinolysis in thyroid dysfunction," Endocrine, vol. 36, no. 1, pp. 110-118, 2009.

[88] R. Chadarevian, E. Bruckert, L. Leenhardt, P. Giral, A. Ankri, and G. Turpin, "Components of the fibrinolytic system are differently altered in moderate and severe hypothyroidism," Journal of Clinical Endocrinology and Metabolism, vol. 86, no. 2, pp. 732-737, 2001.

[89] M. Erdogan, A. Canataroglu, S. Ganidagli, and M. Kulaksızoglu, "Metabolic syndrome prevelance in subclinic and overt hypothyroid patients and the relation among 
metabolic syndrome parameters," Journal of Endocrinological Investigation. In press.

[90] G. Dimitriadis, P. Mitrou, V. Lambadiari et al., "Insulin action in adipose tissue and muscle in hypothyroidism," Journal of Clinical Endocrinology and Metabolism, vol. 91, no. 12, pp. 4930-4937, 2006.

[91] O. Giménez-Palop, G. Giménez-Pérez, D. Mauricio et al., "Circulating ghrelin in thyroid dysfunction is related to insulin resistance and not to hunger, food intake or anthropometric changes," European Journal of Endocrinology, vol. 153, no. 1, pp. 73-79, 2005.

[92] A. Caixàs, R. Tirado, J. Vendrell et al., "Plasma visfatin concentrations increase in both hyper and hypothyroid subjects after normalization of thyroid function and are not related to insulin resistance, anthropometric or inflammatory parameters," Clinical Endocrinology, vol. 71, no. 5, pp. 733-738, 2009.

[93] G. Dimitriadis, E. Maratou, E. Boutati et al., "IGF-I increases the recruitment of GLUT4 and GLUT3 glucose transporters on cell surface in hyperthyroidism," European Journal of Endocrinology, vol. 158, no. 3, pp. 361-366, 2008.

[94] G. Dimitriadis, M. Parry-Billings, S. Bevan et al., "The effects of insulin on transport and metabolism of glucose in skeletal muscle from hyperthyroid and hypothyroid rats," European Journal of Clinical Investigation, vol. 27, no. 6, pp. 475-483, 1997.

[95] E. Çakal, A. T. Turgut, B. Demirbas et al., "Effects of L-thyroxine replacement therapy on carotid intima-media thickness in patients with primary hypothyroidism," Experimental and Clinical Endocrinology and Diabetes, vol. 117, no. 6, pp. 294-300, 2009.

[96] T. Nagasaki, M. Inaba, Y. Kumeda et al., "Decrease of arterial stiffness at common carotid artery in hypothyroid patients by normalization of thyroid function," Biomedicine and Pharmacotherapy, vol. 59, no. 1-2, pp. 8-14, 2005.

[97] L. Vanhaelst, P. Neve, and P. A. Bastenie, "Coronary-artery disease in myxoedema," The Lancet, vol. 2, no. 7528, pp. 1257-1258, 1967.

[98] A. D. Steinberg, "Myxedema and coronary artery disease-a comparative autopsy study," Annals of Internal Medicine, vol. 68, no. 2, pp. 338-344, 1968.

[99] A. I. Qureshi, M. F. K. Suri, A. Nasar, J. F. Kirmani, A. A. Divani, and W. H. Giles, "Free Thyroxine Index and risk of stroke: results from the National Health and Nutrition Examination Survey follow-up study," Medical Science Monitor, vol. 12, no. 12, pp. CR501-CR506, 2006.

[100] D. Liu, F. Jiang, Z. Shan et al., "A cross-sectional survey of relationship between serum TSH level and blood pressure," Journal of Human Hypertension, vol. 24, no. 2, pp. 134-138, 2010.

[101] T. Nagasaki, M. Inaba, Y. Kumeda et al., "Increased pulse wave velocity in subclinical hypothyroidism," Journal of Clinical Endocrinology and Metabolism, vol. 91, no. 1, pp. 154-158, 2006.

[102] Y. Duan, W. Peng, X. Wang et al., "Community-based study of the association of subclinical thyroid dysfunction with blood pressure," Endocrine, vol. 35, no. 2, pp. 136-142, 2009.

[103] J. P. Walsh, A. P. Bremner, M. K. Bulsara et al., "Subclinical thyroid dysfunction and blood pressure: a community-based study," Clinical Endocrinology, vol. 65, no. 4, pp. 486-491, 2006.

[104] F. Toruner, A. E. Altinova, A. Karakoc et al., "Risk factors for cardiovascular disease in patients with subclinical hypothyroidism," Advances in Therapy, vol. 25, no. 5, pp. 430-437, 2008.
[105] E. Şengul, B. Çetinarslan, I. Tarkun, Z. Cantürk, and E. Türemen, "Homocysteine concentrations in subclinical hypothyroidism," Endocrine Research, vol. 30, no. 3, pp. 351359, 2004.

[106] R. D. Lindeman, L. J. Romero, D. S. Schade, S. Wayne, R. N. Baumgartner, and P. J. Garry, "Impact of subclinical hypothyroidism on serum total homocysteine concentrations, the prevalence of coronary heart disease (CHD), and CHD risk factors in the New Mexico Elder Health Survey," Thyroid, vol. 13, no. 6, pp. 595-600, 2003.

[107] W. J. Hueston, D. E. King, and M. E. Geesey, "Serum biomarkers for cardiovascular inflammation in subclinical hypothyroidism," Clinical Endocrinology, vol. 63, no. 5, pp. 582-587, 2005.

[108] R. Luboshitzky, A. Aviv, P. Herer, and L. Lavie, "Risk factors for cardiovascular disease in women with subclinical hypothyroidism," Thyroid, vol. 12, no. 5, pp. 421-425, 2002.

[109] A. R. Cappola, L. P. Fried, A. M. Arnold et al., "Thyroid status, cardiovascular risk, and mortality in older adults," Journal of the American Medical Association, vol. 295, no. 9, pp. 1033-1041, 2006.

[110] C. H. Jung, K. C. Sung, H. S. Shin et al., "Thyroid dysfunction and their relation to cardiovascular risk factors such as lipid profile, hsCRP, and waist hip ratio in Korea," The Korean Journal of Internal Medicine, vol. 18, no. 3, pp. 146-153, 2003.

[111] A. Tuzcu, M. Bahceci, D. Gokalp, Y. Tuzun, and K. Gunes, "Subclinical hypothyroidism may be associated with elevated high-sensitive C-reactive protein (low grade inflammation) and fasting hyperinsulinemia," Endocrine Journal, vol. 52, no. 1, pp. 89-94, 2005.

[112] S. Razvi, J. U. Weaver, M. P. Vanderpump, and S. H. S. Pearce, "The incidence of ischemic heart disease and mortality in people with subclinical hypothyroidism: reanalysis of the Whickham survey cohort," Journal of Clinical Endocrinology and Metabolism, vol. 95, no. 4, pp. 1734-1740, 2010.

[113] S. Singh, J. Duggal, J. Molnar, F. Maldonado, C. P. Barsano, and R. Arora, "Impact of subclinical thyroid disorders on coronary heart disease, cardiovascular and all-cause mortality: a meta-analysis," International Journal of Cardiology, vol. 125, no. 1, pp. 41-48, 2008.

[114] N. Rodondi, D. Aujesky, E. Vittinghoff, J. Cornuz, and D. C. Bauer, "Subclinical hypothyroidism and the risk of coronary heart disease: a meta-analysis," American Journal of Medicine, vol. 119, no. 7, pp. 541-551, 2006.

[115] N. Ochs, R. Auer, D. C. Bauer et al., "Meta-analysis: subclinical thyroid dysfunction and the risk for coronary heart disease and mortality," Annals of Internal Medicine, vol. 148, no. 11, pp. 832-845, 2008.

[116] S. Razvi, A. Shakoor, M. Vanderpump, J. U. Weaver, and S. H.S. Pearce, "The influence of age on the relationship between subclinical hypothyroidism and ischemic heart disease: a metaanalysis," Journal of Clinical Endocrinology and Metabolism, vol. 93, no. 8, pp. 2998-3007, 2008.

[117] B. K. Goksel, M. Karatas, A. Nebioglu et al., "Subclinical hypothyroidism, hyperhomocysteinemia and dyslipidemia: investigating links with ischemic stroke in Turkish patients," Neurological Research, vol. 29, no. 8, pp. 871-876, 2007.

[118] S. K. Jeong, J. Y. Seo, H. S. Nam, and H. K. Park, "Thyroid function and internal carotid artery stenosis in ischemic stroke," Endocrine Journal, vol. 57, no. 8, pp. 711-718, 2010.

[119] M. Alevizaki, M. Synetou, K. Xynos, C. C. Alevizaki, and K. N. Vemmos, "Hypothyroidism as a protective factor in acute stroke patients," Clinical Endocrinology, vol. 65, no. 3, pp. 369-372, 2006. 
[120] J. H. Baek, P. W. Chung, Y. B. Kim et al., "Favorable influence of subclinical hypothyroidism on the functional outcomes in stroke patients," Endocrine Journal, vol. 57, no. 1, pp. 23-29, 2010.

[121] N. Rodondi, A. B. Newman, E. Vittinghoff et al., "Subclinical hypothyroidism and the risk of heart failure, other cardiovascular events, and death," Archives of Internal Medicine, vol. 165, no. 21, pp. 2460-2466, 2005.

[122] L. M. Prisant, J. S. Gujral, and A. L. Mulloy, "Hyperthyroidism: a secondary cause of isolated systolic hypertension," Journal of Clinical Hypertension, vol. 8, no. 8, pp. 596-599, 2006.

[123] K. M. Colleran, D. M. Ratliff, and M. R. Burge, "Potential association of thyrotoxicosis with vitamin $\mathrm{B}$ and folate deficiencies, resulting in risk for hyperhomocysteinemia and subsequent thromboembolic events," Endocrine Practice, vol. 9, no. 4, pp. 290-295, 2003.

[124] P. Mitrou, E. Boutati, V. Lambadiari et al., "Insulin resistance in hyperthyroidism: the role of IL6 and TNF $\alpha$," European Journal of Endocrinology, vol. 162, no. 1, pp. 121-126, 2010.

[125] G. Dimitriadis, P. Mitrou, V. Lambadiari et al., "Glucose and lipid fluxes in the adipose tissue after meal ingestion in hyperthyroidism," Journal of Clinical Endocrinology and Metabolism, vol. 91, no. 3, pp. 1112-1118, 2006.

[126] J. Al Jaber, S. Haque, H. Noor, B. Ibrahim, and J. Al Suwaidi, "Thyrotoxicosis and coronary artery spasm: case report and review of the literature," Angiology, vol. 61, no. 8, pp. 807$812,2010$.

[127] R. A. Chudleigh and J. S. Davies, "Graves' thyrotoxicosis and coronary artery spasm," Postgraduate Medical Journal, vol. 83, no. 985, article e5, 2007.

[128] Y. H. Choi, J. H. Chung, S. W. Bae et al., "Severe coronary artery spasm can be associated with hyperthyroidism," Coronary Artery Disease, vol. 16, no. 3, pp. 135-139, 2005.

[129] J. J. Sheu, J. H. Kang, H. C. Lin, and H. C. Lin, "Hyperthyroidism and risk of ischemic stroke in young adults: a 5-year follow-up study," Stroke, vol. 41, no. 5, pp. 961-966, 2010.

[130] J. S. Staffurth, M. C. Gibberd, and S. N. Fui, "Arterial embolism in thyrotoxicosis with atrial fibrillation," British Medical Journal, vol. 2, no. 6088, pp. 688-690, 1977.

[131] S. Bar-Sela, M. Ehrenfeld, and M. Eliakim, "Arterial embolism in thyrotoxicosis with atrial fibrillation," Archives of Internal Medicine, vol. 141, no. 9, pp. 1191-1192, 1981.

[132] A. Squizzato, V. E. A. Gerdes, D. P. M. Brandjes, H. R. Büller, and J. Stam, "Thyroid diseases and cerebrovascular disease," Stroke, vol. 36, no. 10, pp. 2302-2310, 2005.

[133] H. Völzke, T. Ittermann, C. O. Schmidt et al., "Subclinical hyperthyroidism and blood pressure in a population-based prospective cohort study," European Journal of Endocrinology, vol. 161, no. 4, pp. 615-621, 2009.

[134] H. Völzke, D. M. Robinson, U. Schminke et al., "Thyroid function and carotid wall thickness," Journal of Clinical Endocrinology and Metabolism, vol. 89, no. 5, pp. 2145-2149, 2004. 

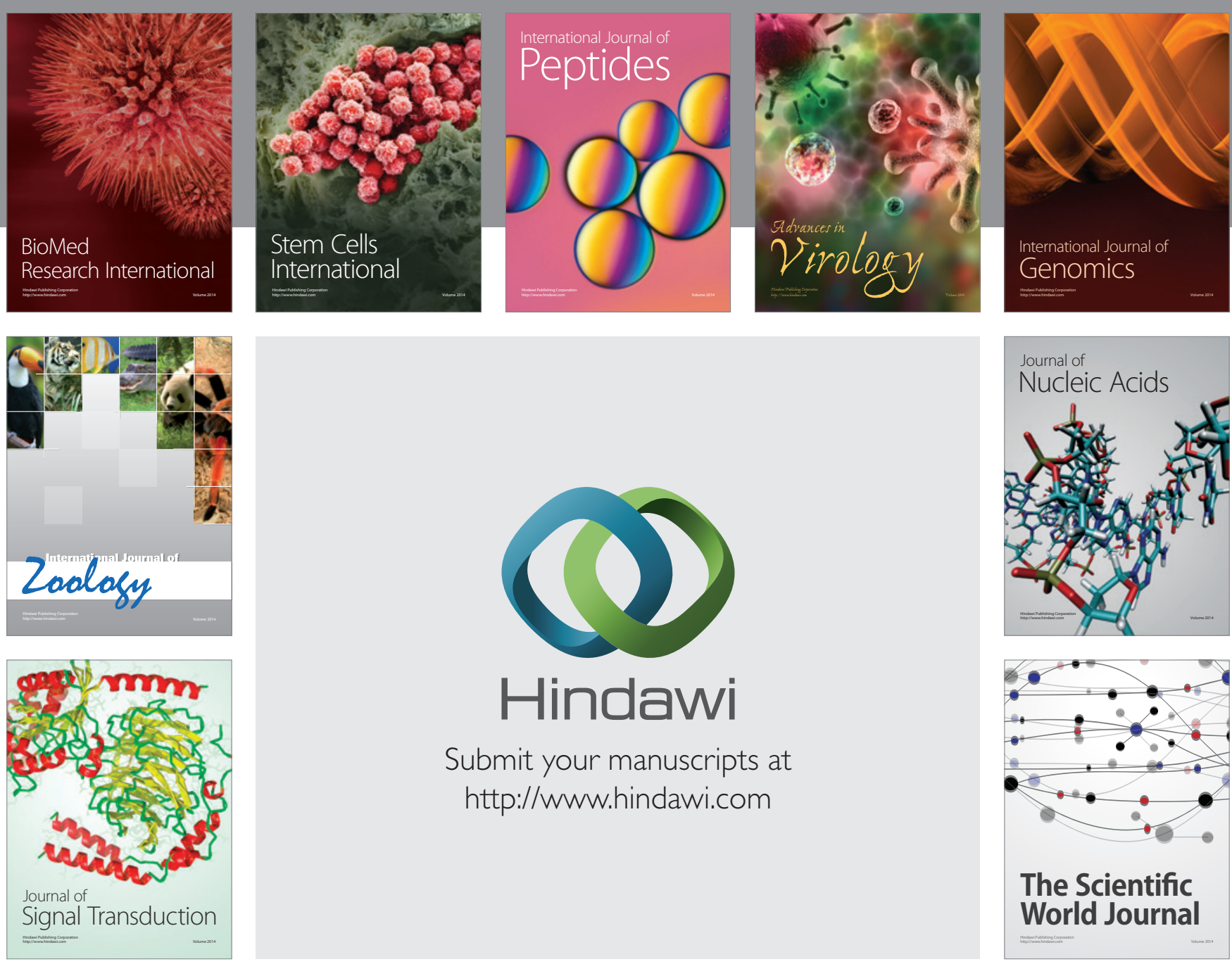

Submit your manuscripts at

http://www.hindawi.com
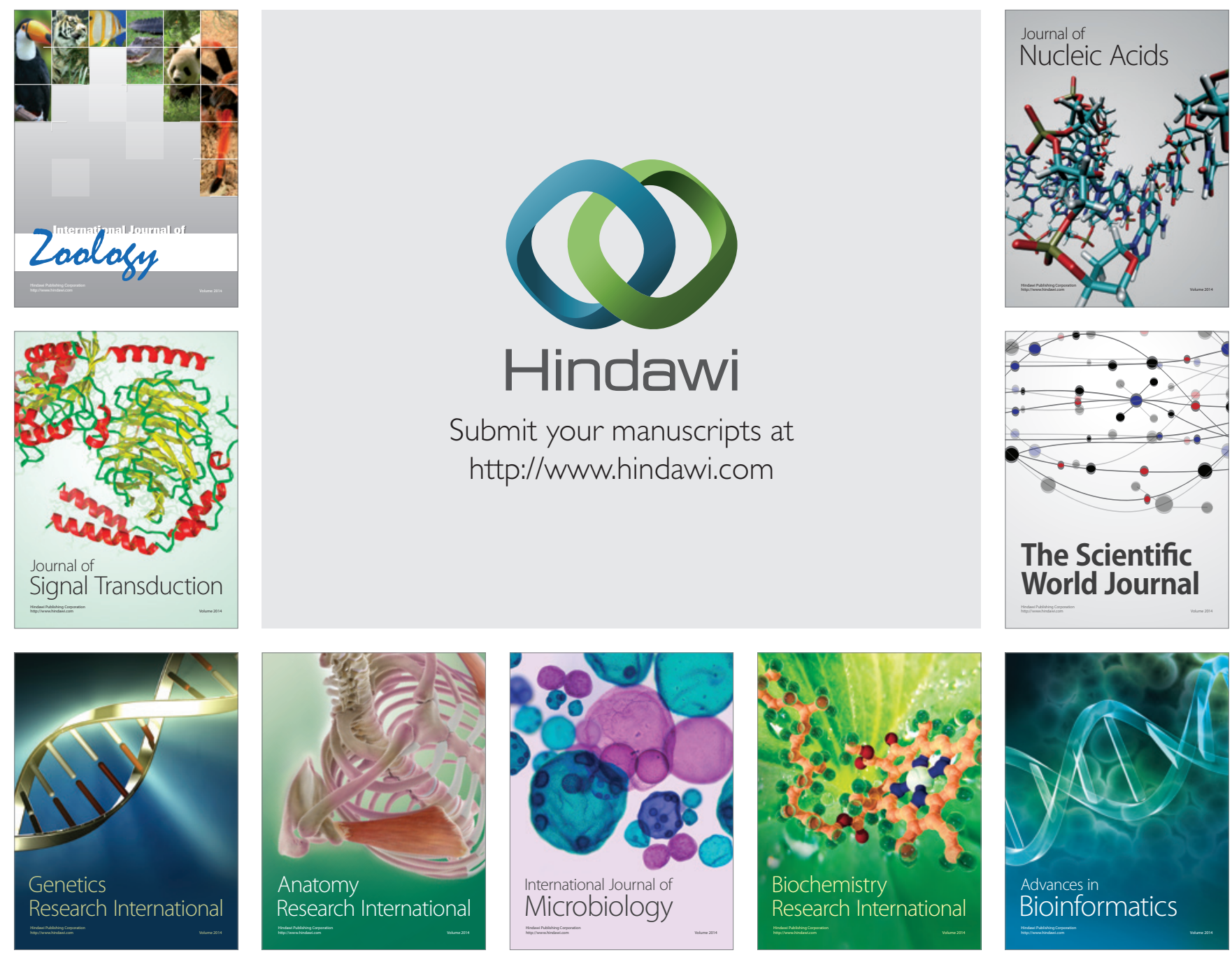

The Scientific World Journal
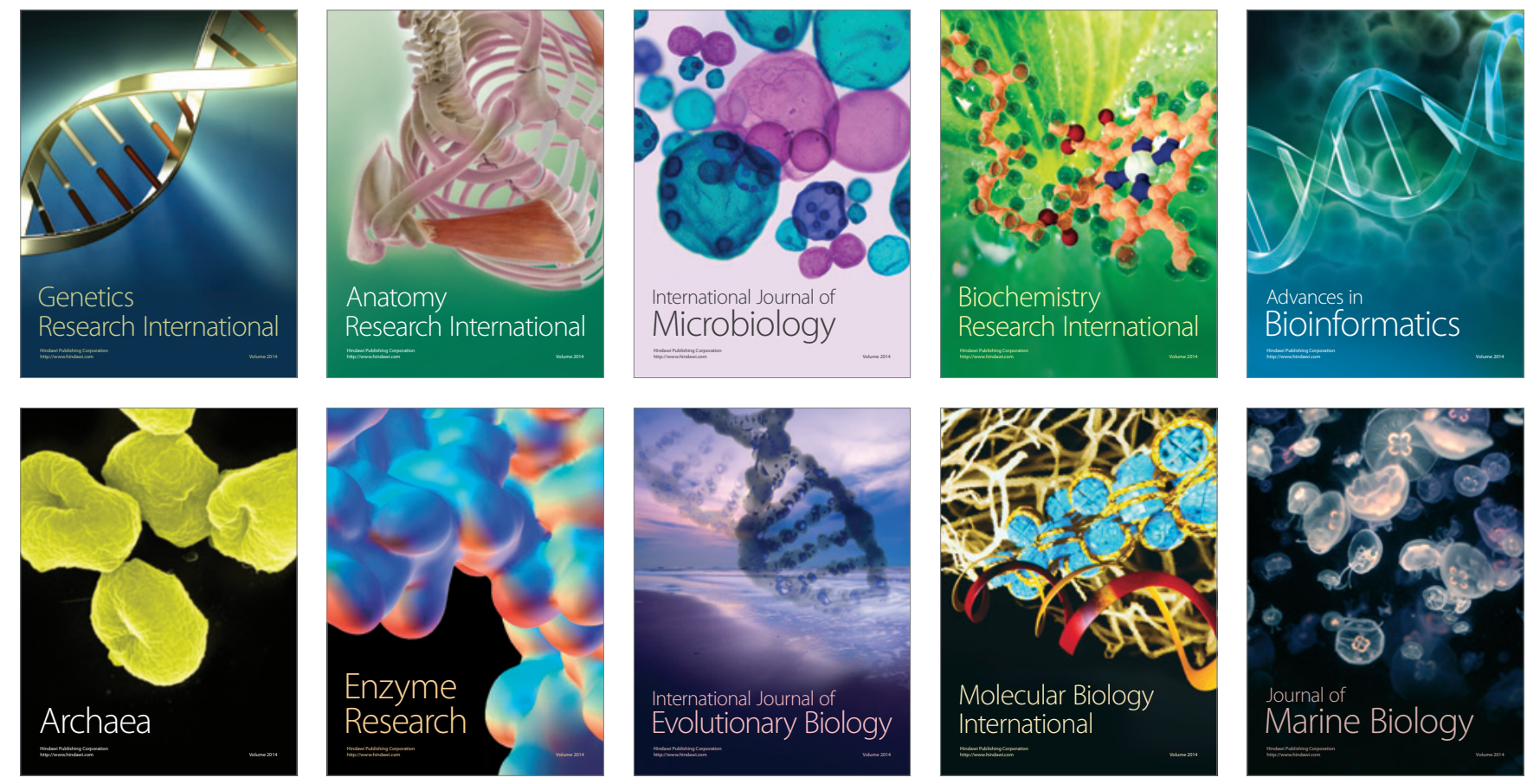